\title{
Zoochorous dispersal of freshwater bivalves: an overlooked vector in biological invasions?
}

\author{
Neil E. Coughlan ${ }^{1,2,3, *}$, Andrew L. Stevens ${ }^{4}$, Thomas C. Kelly ${ }^{3}$, Jaimie T.A. Dick ${ }^{1}$ and \\ Marcel A.K. Jansen ${ }^{3}$ \\ ${ }^{1}$ Institute for Global Food Security, School of Biological Sciences, Queen's University Belfast, Medical Biology Centre, \\ 97 Lisburn Rd, Belfast BT9 7BL, Northern Ireland \\ ${ }^{2}$ Centre for Environmental Research, Innovation \& Sustainability, Institute of Technology Sligo, Ash Lane, Co. Sligo, Ireland \\ ${ }^{3}$ School of Biological, Earth and Environmental Sciences, University College Cork, Distillery Field, North Mall, Cork, Ireland \\ ${ }^{4}$ Center for Limnology, University of Wisconsin-Madison, Madison, WI, USA
}

\begin{abstract}
Vectors that underpin the natural dispersal of invasive alien species are frequently unknown. In particular, the passive dispersal (zoochory) of one organism (or propagule) by another, usually more mobile animal, remains poorly understood. Field observations of the adherence of invasive freshwater bivalves to other organisms have prompted us to assess the importance of zoochory in the spread of three prolific invaders: zebra mussel Dreissena polymorpha; quagga mussel Dreissena bugensis; and Asian clam Corbicula fluminea. An extensive, systematic search of the literature was conducted across multiple on-line scientific databases using various search terms and associated synonyms. In total, only five publications fully satisfied the search criteria. It appears that some fish species can internally transport viable adult $D$. polymorpha and $C$. fluminea specimens. Additionally, literature indicates that veligers and juvenile $D$. polymorpha can adhere to the external surfaces of waterbirds. Overall, literature suggests that zoochorous dispersal of invasive bivalves is possible, but likely a rare occurrence. However, even the establishment of a few individuals (or a single self-fertilising $C$. fluminea specimen) can, over-time, result in a substantial population. Here, we highlight knowledge gaps, identify realistic opportunities for data collection, and suggest management protocols to mitigate the spread of invasive alien species.
\end{abstract}

Keywords: ectozoochory / endozoochory / freshwater ecosystems / ichthyochory / invasive alien / secondary spread

Résumé - Zoochorie de bivalves d'eau douce ; un vecteur négligé dans les invasions biologiques ? Les vecteurs qui sous-tendent la dispersion naturelle des espèces exotiques envahissantes sont souvent inconnus. En particulier, la dispersion passive (zoochorie) d'un organisme (ou propagule) par un autre, habituellement plus mobile, reste mal comprise. Les observations sur le terrain de l'adhésion des bivalves d'eau douce envahissants à d'autres organismes nous ont incité à évaluer l'importance de la zoochorie dans la propagation de trois envahisseurs prolifiques : la moule zébrée Dreissena polymorpha; Moule Quagga Dreissena bugensis; et la palourde asiatique Corbicula fluminea. Une recherche approfondie et systématique de la littérature a été menée dans de multiples bases de données scientifiques en ligne utilisant différents termes de recherche et synonymes associés. Au total, seulement cinq publications ont pleinement satisfait les critères de recherche. Il semble que certaines espèces de poissons puissent transporter intérieurement des spécimens adultes viables de $D$. polymorpha et $C$. fluminea. En outre, la littérature indique que les véligères et les $D$. polymorpha juvéniles peuvent adhérer aux surfaces externes des oiseaux d'eau. Dans l'ensemble, la littérature suggère que la dispersion par zoochorie des bivalves invasifs est possible, mais probablement une occurrence rare. Cependant, même l'établissement de quelques individus (ou un seul spécimen autofécondant de C. Aluminea) peut, au fil du temps, entraîner une population importante. Ici, nous mettons en évidence les lacunes en matière de connaissances, identifions des opportunités réalistes pour la collecte de données et proposons des protocoles de gestion pour atténuer la propagation d'espèces exotiques envahissantes.

\footnotetext{
*Corresponding author: neil.coughlan.zoology@gmail.com
} 
Mots-clés : ectozoochorie / endozoochorie / écosystèmes d'eau douce / ichthychorie / espèce exotique invasive / propagation secondaire

\section{Introduction}

The majority of primary introductions of invasive alien species (IAS) are considered to have occurred via anthropogenic means (Hulme et al., 2008; Solarz et al., 2017). However, the natural (or 'unaided by humans') dispersal of organisms can also result in the arrival of an IAS in a new region (Hulme et al., 2016). More importantly, the secondary spread of IAS from an established source population can often be facilitated by natural dispersal vectors, including water currents (hydrochory), wind (anemochory), and other animals (zoochory) (Bilton et al., 2001; Hulme et al., 2008; Coughlan et al., 2017b). Recent European Union (EU) and United States of America (USA) legislation (EU Regulation 1143/ 2014 and Safeguarding the Nation from the Impacts of Invasive Species-amendment to Executive Order 13112, respectively) seek to prevent, control and eradicate IAS within both territories. In order to develop comprehensive IAS prevention and control measures, species risk assessments must consider not only broad invasion pathway categories, but also specific vectors (Essl et al., 2015). Currently, however, our understanding of the natural dispersal processes operating between hydrologically unconnected water bodies remains limited (Soomers et al., 2013; Incagnone et al., 2015; Coughlan et al., 2017a).

Zoochorous transport of one organism by another more mobile animal can facilitate dispersal of various taxa (see Fig. 1) (Reynolds et al., 2015; Green, 2016; Coughlan et al., 2017a). Many organisms, particularly propagule stages (e.g., seeds, spores, eggs, ephippia, gemmules, statoblasts, or cysts) can be transported both internally, via the gastrointestinal tract (gut), or upon the exterior surfaces of other animals. The association where one organism (or propagule) is externally transported by another organism is categorised under various biological relationships which include, inter alia, ectozoochory, phoresis, commensalism, and fouling. Ectozoochory (synonyms epizoochory, exozoochory), a term originally used to describe the dispersal of plant propagules via external adherence to animal vectors, is now widely employed to refer to external dispersal of a variety of taxa (Reynolds et al., 2015; Green, 2016; Coughlan et al., 2017a). Endozoochory, a term originally used to describe seed dispersal, now encompasses the internal dispersal of a variety of taxa.

The spread of invasive alien bivalves represents a major threat to the function and biodiversity of freshwater ecosystems worldwide (Strayer et al., 1999; Sousa et al., 2009; Higgins and Vander Zanden, 2010; Douda et al., 2017). In particular, zebra mussel Dreissena polymorpha (Pallas, 1771), quagga mussel, Dreissena bugensis (Andrusov, 1897) and Asian clam Corbicula fluminea (Müller, 1774) are prolific invaders, whose presence can have damaging ecological and economic consequences for invaded habitats (Pimentel et al., 2005; Sousa et al., 2014; Karatayev et al., 2015). Moreover, despite management efforts to reduce invader spread within EU and USA territories, further range expansion of these bivalves has been observed (e.g., Aldridge et al., 2014; Benson, 2014; Caffrey et al., 2016). Under optimal conditions, these bivalve species display rapid growth and high levels of fecundity, and can potentially form flourishing populations from a few founder specimens, or in the cases of $C$. fluminea, from even one self-fertilising individual (McMahon, 2002). In contrast to many freshwater bivalve species, the life cycles of these invaders do not include a parasitic larval stages (Mackie, 1991). Rather, planktonic larval (e.g., veliger) stages can freely swim within the water column until settlement of the post-veliger (e.g., juvenile) stages occurs. Both up-stream and between catchment dispersal of these bivalves has been predominantly attributed to anthropogenic activities, particularly by recreational water users (e.g., anglers, boaters, and canoeists) (Kappes and Haase, 2012; Banha et al., 2016). Nevertheless, possible alternative natural vectors of passive dispersal remain under-researched, even though these vectors may facilitate greater levels of invasive bivalve dispersal than is assumed (Johnson and Carlton, 1996; Kappes and Haase, 2012; Banha et al., 2016). Field observations of D. polymorpha attachment to more mobile freshwater organisms (see Fig. 2) have prompted us to assess the importance of zoochory in the spread of invasive freshwater bivalves. Here, we examine the available literature concerning zoochorous dispersal of invasive freshwater bivalves: D. polymorpha; D. bugensis; and $C$. fluminea.

\section{Methods}

We systematically searched for relevant material using the on-line scientific databases Thomson-Reuters Web of Science and Scopus. An additional search for relevant material was preformed using Google and Google Scholar. All searches were undertaken in December 2016, and focused on various terms used in the literature. For example, the principle search term used to derive relevant material was: (mussel OR clam OR bivalv* OR dreissena OR corbicula) AND (external OR internal OR passive OR vector OR foul* OR * zoochorous OR *chory OR *zoon OR phor* OR gut OR *intestinal) AND (dispersal OR dispersion). Species scientific names (D. polymorpha, D. bugensis and C. fluminea) and common names were also used as search terms. Associated synonyms of search terms (e.g., epizoon, entozoon, ectozoochory, endozoochory, passive dispersal, fouling, phoresy) were further used to assess and reduce the number of generated documents. Moreover, reference lists from all retrieved books and articles were screened for other relevant publications. Selected literature was then appraised for inclusion within this paper based upon pertinence to the core topic, e.g., studies which directly evaluate zoochorous mediated dispersal of $D$. polymorpha, D. bugensis or C. fluminea. There was no restriction on publication year.

\section{Results and discussion}

The search yielded 219 and 161 publications from Web of Science and Scopus, respectively. Google and Google Scholar did not provide any additional pertinent material, within the 

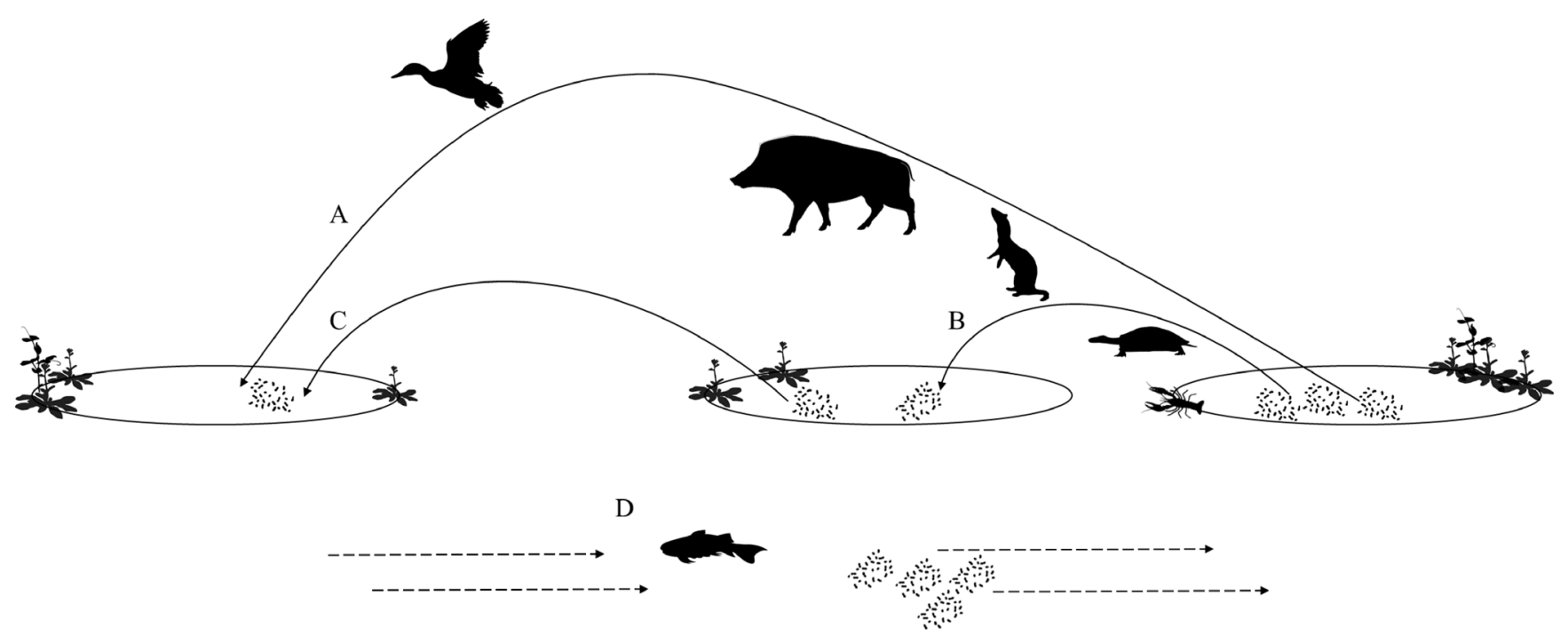

Fig. 1. Overland long distance dispersal (LDD) (A), short distance dispersal (SDD) (B), and 'stepping stone' dispersal (C) of invasive bivalve species (dot clusters) between isolated (e.g., hydrologically unconnected) freshwater sites via possible zoochorous vectors. Equally, when sites are hydrologically connected (D) (e.g., streams) additional aquatic vectors, such as fish species, may facilitate LDD, SDD or stepping stone dispersal. Moreover, zoochorous vectors may intensify invader spread across large aquatic areas (e.g., large lakes). Dashed lines indicate water current.

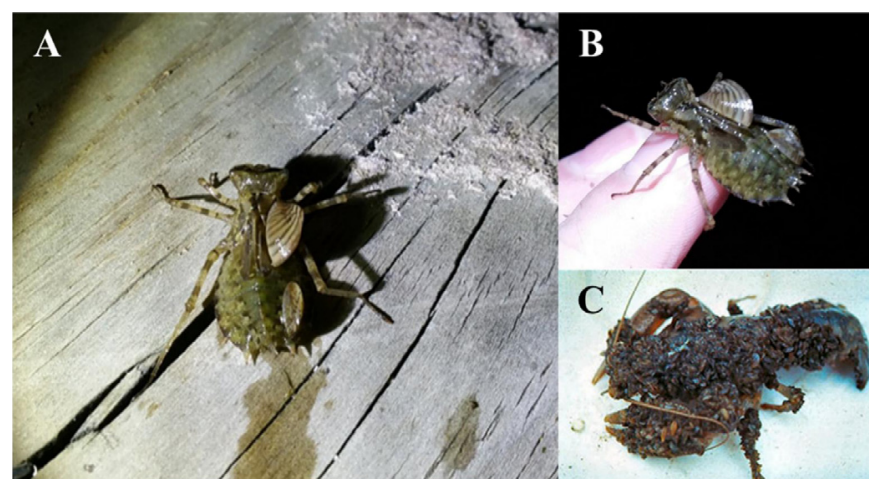

Fig. 2. (A \& B) Two adult zebra mussels Dreissena polymorpha attached to the dorsal carapace of an odonata nymph Epicordulia sp. (Corduliidae) larva. The nymph was collected on Lake Mendota, Madison, WI $\left(43^{\circ} 04^{\prime} 38.8^{\prime \prime} \mathrm{N} 89^{\circ} 24^{\prime} 10.6^{\prime \prime} \mathrm{W}\right)$ on 24 th October 2016 via a minnow trap in $2 \mathrm{~m}$ of water (Photo credits, A.L. Stevens). The criteria used to identify species are described by Bouchard et al. (2004). (C) Adult crayfish specimen extensively fouled by $D$. polymorpha (Photo credit, Minnesota Department of Natural Resources).

first ten search-pages. Numerous studies suggested zoochory as a potential dispersal mechanism for various freshwater bivalves and other Mollusca species, however, many did not reference a citation for this assumption. Studies selected for inclusion within this paper are those which attempted to experimentally examine zoochorous dispersal of $D$. polymorpha, D. bugensis, or C. fluminea. In total, only five publications met the full search criteria (Tab. 1).

\subsection{Endozoochorous dispersal}

Many studies have reported the consumption of invasive bivalves by fish and bird species (e.g., Robinson and Wellborn,
1988; Hamilton and Davison Ankney, 1994; Tuckeret al., 1996). In most cases, gut contents or faecal samples appear to suggest that the consumer can effectively digest $D$. polymorpha, D. bugensis and C. fluminea leaving only shell fragments (e.g., Hamilton and Davison Ankney, 1994; Tuckeret al., 1996; Perelloet al., 2015). However, most studies do not examine endozoochorous dispersal and, therefore, do not attempt to assess the survival and viability of intact specimens (if any) found within retrieved gut or faecal samples. Equally, a variety of freshwater mollusca, such as pea clams (Sphaeriidae), valve snails (Valvatidae), pond snails (Lymnaeidae) and mussels (Mytilidae), have been shown to survive gut passage through different fish and waterbird species, albeit to various extents (Mackie, 1979; Brown, 2007; Belz et al., 2012; van Leeuwen et al., 2012).

Literature reviewed here (and many fish and waterbird dietary studies) indicate (or imply) that D. polymorpha, D. bugensis, and $C$. fluminea will not usually survive gut passage. Remarkably, Gatlin et al. (2013) recorded the survival of $C$. fluminea and D. polymorpha that have passed through the gut of migratory blue catfish (Ictalurus furcatus), a species which travels up to $689 \mathrm{~km}$ in a year (Tripp et al., 2011). However, any intact bivalve specimens are more likely to be ejected over much shorter distances as dictated by gut retention times. Moreover, Gatlin et al. (2013) noted that these bivalves appear unable to survive gut passage through I. furcatus in waters above $21.1^{\circ} \mathrm{C}$, however, this is unlikely to overly inhibit dispersal potential as migrations typically occur when water temperatures are between 8 and $18^{\circ} \mathrm{C}$. Incidentally, we hypothesise that the observed increase in bivalve mortality may be due to greater host metabolic activity, as warmer water temperatures may increase digestion efficiency of some fish species (Mizanur et al., 2014; De et al., 2016). Conversely, higher water temperature can also result in reduced retention times within the gastrointestinal tract (De et al., 2016).

The feeding ecology of fish and waterbird species, and associated digestive morphological traits, will likely influence 
N.E. Coughlan et al.: Knowl. Manag. Aquat. Ecosyst. 2017, 418, 42

Table 1. Studies addressing zoochorus dispersal of zebra mussel Dreissena polymorpha, quagga mussel, Dreissena bugensis and Asian clam Corbicula fluminea. The bivalve species examined, method of investigation used, and a summary of findings are identified.

\begin{tabular}{|c|c|c|c|}
\hline Reference & Species & Method & Summary of findings \\
\hline \multicolumn{4}{|l|}{ Endozoochory } \\
\hline Thompson and Sparks (1977) & Corbicula fluminea & $\begin{array}{l}\text { Faecal sample } \\
\text { collection }\end{array}$ & $\begin{array}{l}\text { Live } C \text {. Aluminea feed to lesser scaup ducks } \\
\text { (Aythya affinis) did not survive gut passage. }\end{array}$ \\
\hline Johnson and Carlton (1996) & Dreissena polymorpha & $\begin{array}{l}\text { Faecal sample } \\
\text { collection }\end{array}$ & $\begin{array}{l}\text { Faecal samples recovered from mallard ducks } \\
\text { (Anas platyrhynchos), which consumed juvenile } \\
\text { mussels or concentrated suspensions of veligers, } \\
\text { did not contain any viable specimens. }\end{array}$ \\
\hline Gatlin et al. (2013) & $\begin{array}{l}\text { Corbicula fluminea } \\
\text { Dreissena polymorpha }\end{array}$ & $\begin{array}{l}\text { Faecal sample } \\
\text { collection }\end{array}$ & $\begin{array}{l}\text { Twelve percent of } D \text {. polymorpha and } 39 \% \text { of } \\
C \text {. fluminea consumed in cool water }\left(<21.1^{\circ} \mathrm{C}\right) \\
\text { survived gut passage through migratory blue } \\
\text { catfish (Ictalurus furcatus). }\end{array}$ \\
\hline Mack and Andraso (2015) & $\begin{array}{l}\text { Dreissena bugensis } \\
\text { Dreissena polymorpha }\end{array}$ & $\begin{array}{l}\text { Faecal sample } \\
\text { collection }\end{array}$ & $\begin{array}{l}\text { No dreissenids survived passage through the } \\
\text { gut of round goby (Neogobius melanostomus). }\end{array}$ \\
\hline \multicolumn{4}{|l|}{ Ectozoochory } \\
\hline Johnson and Carlton (1996) & Dreissena polymorpha & $\begin{array}{l}\text { Experimental } \\
\text { attachment }\end{array}$ & $\begin{array}{l}\text { Veligers and juvenile } D \text {. polymorpha transported } \\
(2.5 \mathrm{~m}) \text { between ponds by walking mallard ducks, } \\
<0.5 \text { mussel per trip. }\end{array}$ \\
\hline Banha et al. (2016) & Dreissena polymorpha & $\begin{array}{l}\text { Experimental } \\
\text { attachment }\end{array}$ & $\begin{array}{l}\text { Larvae of } D \text {. polymorpha can adhere and remain } \\
\text { attached to a mallard duck carcass during } \\
\text { simulated swims }\left(\leq 0.5 \mathrm{~m} \mathrm{~s}^{-1}\right) \text { and flights }\left(75 \mathrm{~km} \mathrm{~h}^{-1}\right) \text {. }\end{array}$ \\
\hline
\end{tabular}

success of endozoochorous dispersal. Vector species that are acclimated to a diet containing bivalves are less likely to facilitate transport than individuals or species which are not. For example, Mack and Andraso (2015) documented no survival of dreissenids after gut passage through the round goby (Neogobius melanostomus). Previously, however, Andraso et al. (2011) had noted that mature N. melanostomus specimens can develop molariform teeth typical of those found in molluscivorous fish to prey on dreissenid mussels. Age, genetic and environmental factors are suggested to influence pharyngeal remodelling. Moreover, Index of Relative Importance analysis of $N$. melanostomus gut contents indicate a diet selective of veliger and juvenile dreissenid mussels (Thompson and Simon, 2014). In contrast, I. furcatus appears to be preferentially more piscivorous, although it is often described as an omnivorous opportunistic feeder (MacAvoy et al., 2000; Aguilar et al., 2016). Therefore, ceteris paribus, the digestion of bivalves by $I$. furcatus may be less efficient than digestion by adult $N$. melanostomus.

Many waterbird species are also known to consume bivalves (Piersma et al., 1993; Hamilton and Davison Ankney, 1994). Thompson and Sparks (1977) observed that lesser scaup ducks (Aythya affinis) digested C. fluminea completely. However, A. affinis is a preferential rather than opportunistic consumer of macroinvertebrates (Gurney et al., 2017). Within phylogenetic or ecological constraints, the avian digestive tract can respond to variable diet composition and quality by changing morphology and/or activities of digestive enzymes (Piersma et al., 1993; van Gils et al., 2003; Kohl et al., 2017). Therefore, we argue that prior to acclimation of the gastrointestinal tract to the presence of bivalves within their diet, some waterbirds may facilitate endozoochorous dispersal. In support of such an argument, van Leeuwen et al. (2012) retrieved greater numbers of intact aquatic snail species from faecal samples obtained from smaller mallard ducks compared to larger individuals. This was surmised to reflect shorter retention times by smaller ducks, given that gut length and gizzard size are generally correlated to body mass. Accordingly, snails likely experienced less exposure to both gastric enzymes and abrasive mechanical digestion by the avian gizzard.

It appears that the thermal shock of sudden exposure to the high internal body temperatures of waterbirds $\left(42^{\circ} \mathrm{C}\right)$, and possibly hypoxia, can induce high mortality of $C$. fluminea, which generally does not tolerate water temperatures above $38^{\circ} \mathrm{C}$ (McMahon, 1979; Lucy et al., 2012). Similarly, the upper thermal limit of $D$. bugensis is likely between 25 and $36^{\circ} \mathrm{C}$ (Spidle et al., 1995). However, warm water $\left(>15^{\circ} \mathrm{C}\right)$ acclimated $D$. polymorpha can survive water temperatures up to $40{ }^{\circ} \mathrm{C}$ for between 20 and 75 minutes, depending on the rate of temperature increase (McMahon and Ussery, 1995; Spidle et al., 1995; Beyer et al., 2011) and therefore, may survive rapid passage through the avian gut if exposed to minimal abrasive damage. Accordingly, both fish and waterbird consumer species which are not acclimated to the presence of bivalves within their diet may potentially facilitate a dispersal event.

\subsection{Ectozoochorous dispersal}

Several publications cited anecdotal accounts detailing ectozoochorous dispersal of various bivalve species (see Rees (1965) for a collection of these accounts), no anecdotes concerning the ectozoochorous dispersal of D. polymorpha, $D$. bugensis or $C$. Aluminea were found. However, Johnson and Carlton (1996) observed that walking mallard ducks (Anas platyrhynchos) could transport larvae and juvenile $D$. polymorpha a distance of $2.5 \mathrm{~m}$ between ponds, albeit at a rate of $<0.5$ mussel per trip. More recently, Banha et al. (2016) 
recorded the adherence and continued attachment of $D$. polymorpha larvae to a mallard duck carcass during simulated swims $\left(\leq 0.5 \mathrm{~m} \mathrm{~s}^{-1}\right)$. Equally, assuming an average flight speed of $75 \mathrm{~km} \mathrm{~h}^{-1}$, Banha et al. calculate that adhering larvae could be transported $145 \mathrm{~km}$ by ducks in a long-distance dispersal (LDD) event, with a $50 \%$ chance of survival.

The adherence (or biofouling) of $D$. polymorpha to other freshwater inhabitants such as Gastropoda, crayfish species, and dragonfly (Insecta: Odonata) nymphs has been well documented (e.g. Fincke and Tylczak, 2011). In particular, D. polymorpha, which is capable of secondary settlement and active reattachment, has been observed to attach, detach and subsequently reattach to Odonata nymphs and crayfish hosts when in search of a suitable substrate to inhabit (Fig. 2) (Duriš et al., 2007; Hughes and Fincke, 2012). Interestingly, both Odonata nymphs and freshwater crayfish species are capable of short overland translocation between waterbodies. Moreover, these host species can shed their entire 'mussel load' upon cuticle moult, which is likely to deposit any adhering bivalves within the freshwater system (Duriš et al., 2007; Hughes and Fincke, 2012). Surprisingly, our review of the literature indicates that the adherence of dreissenidae to mobile invertebrates has not been examined in the context of zoochorous dispersal.

Equally, no experimental studies concerning the role of birds - or indeed, large semi-aquatic and/or mud wallowing vertebrate species (e.g. otters, boars, muskrats etc.) - as possible vectors of ectozoochorous dispersal for D. bugensis or $C$. fluminea were obtained from the literature. Both Johnson and Carlton (1996) and Banha et al. (2016) have shown that waterbirds, such as ducks, can facilitate shortdistance dispersal (SDD) of D. polymorpha veligers. However, over time, SDD may lead to LDD through multiple SDD events; collectively known as 'stepping-stone' dispersal (Fig. 1) (Coughlan et al., 2017a, 2017b). Additionally, while Johnson and Carlton (1996) suggest that the rate of attachment of $D$. polymorpha to waterbirds is low, only scant experimental detail is provided. Studies such as Águas et al. (2014), Anastácio et al. (2014), and Banha et al. (2016) have highlighted the importance of aquatic invertebrate densities, water depth and exposure time upon the probability of aquatic invertebrate contact and attachment with waterbirds. Accordingly, the density of waterbirds will also influence the probability of contact with aquatic invertebrates and subsequent bird-mediated ectozoochorous dispersal (Coughlan et al., 2017a). While ectozoochorous dispersal of D. bugensis and $C$. fluminea has not been examined, these species are likely to adhere to waterbirds in a similar fashion to D. polymorpha. In particular, the production of ctenidial mucillagineous (byssal) threads by juvenile $C$. fluminea are thought to aid floatation, zoochory and anthropogenic dispersal (McMahon, 1982).

If adherence is maintained, bivalves will need to survive the translocation process. This will likely become particularly arduous should a vector leave the aquatic medium. Ricciardi et al. (1995) indicated that adult D. polymorpha can survive (77.5\% of specimens) $24 \mathrm{hrs}$ aerial exposure at $30{ }^{\circ} \mathrm{C}$ and $50 \%$ relative humidity (RH). Greater survival $(96.7 \%)$ was observed under colder conditions $\left(20^{\circ} \mathrm{C}\right.$ and $\left.50 \% \mathrm{RH}\right)$. In contrast, only $40 \%$ of $D$. bugensis specimens survived $24 \mathrm{hr}$ exposure to these colder conditions $\left(20^{\circ} \mathrm{C}\right.$ and $\left.50 \% \mathrm{RH}\right)$. In addition, Byrne et al.
(1988) observed a 50\% mortality rate in adult $C$. fluminea aerially exposed to $25^{\circ} \mathrm{C}$ and $53 \% \mathrm{RH}$ for $73 \mathrm{hrs}$. However, specimens exposed to warmer conditions $\left(35^{\circ} \mathrm{C}\right.$ and $\left.53 \% \mathrm{RH}\right)$ displayed $50 \%$ mortality after $24 \mathrm{hrs}$. Recently, Coughlan et al. $(2015 \mathrm{a}, \mathrm{b})$ measured the microclimatic conditions found within the plumage of mallard ducks. While temperature and RH were found to vary with the external anatomical surfaces (e.g., posterior neck, crural, crissum) of A. platyrhynchos, on average, ducks displayed temperatures of between 21 and $33^{\circ} \mathrm{C}$, and $\mathrm{RH}$ between 58.4 and $72.8 \%$. Therefore, we surmise that even at the highest temperature and lowest $\mathrm{RH}$ combination found within mallard plumage, entangled adult $D$. polymorpha and $C$. fluminea may survive for up to $24 \mathrm{hrs}$, if not longer. Bivalves adhering to the feet of waterbirds are likely to be exposed to cooler temperatures, particularly in more temperate regions. However, temperature and humidity will depend on seasonal and local conditions.

\subsection{Post dispersal}

A suitable receiving environment is essential for successful dispersal (Coughlan et al., 2017a). Freshwater fish do not leave the aquatic medium, and waterbirds often excrete faecal matter within aquatic sites. Thus, it seems reasonable to conclude that if bivalves survive endozoochory, they can be deposited within suitable freshwater habitats. Equally, detachment of an adhering organism can occur at any stage during ectozoochory when attachment fails. Waterbirds frequently move between freshwater sites, and therefore, it is likely that detachment can occur at a suitable location. In particular, bivalves adhering to birds via the 'grip' of their closed gape, may release when brought into contact with freshwater by a vectorbird. For example, Banha et al. (2014) observed that non-native snails (Pysella acuta) maintained attachment to a human vector (offroad vehicle) for circa $100 \mathrm{~km}$, and subsequent detachment was promoted by contact with freshwater. Moreover, many waterbird species will often preen and wash themselves with freshwater, which may facilitate detachment of plumage enmeshed bivalves in a suitable environment.

\section{Conclusion and recommendations}

Our systematic search of the literature revealed only five studies that specifically attempted to examine zoochorous dispersal of invasive D. polymorpha, D. bugensis, or $C$. fluminea. Overall, when taken together, these publications suggest that zoochorous dispersal of invasive freshwater bivalves is possible. However, given that many potential vector species consistently move between invaded and non-invaded sites, and that the recorded rate of invasive spread is often low (e.g., Caffrey et al., 2016), zoochorous LDD may be a limited, if not rare, occurrence (Coughlan et al., 2017a). Correspondingly, the recorded rate of natural up-stream dispersal and overland translocation of these invasive bivalves to adjacent (and hydrologically unconnected) waterbodies is slow (Voelz et al., 1998; Kappes and Haase, 2012). Therefore, in agreement with postulations found within the literature, anthropogenic vectors likely present a higher potential for invasive bivalve dispersal (e.g., Voelz et al., 1998; Kappes and Haase, 2012; Marescaux et al., 2012; Banha et al., 2016; Solarz et al., 2017). 
Moreover, in agreement with Solarz et al. (2017), given the often limited resources available to tackle biological invasions, the challenging question of zoochorous dispersal cannot be a priority management issue. However, there remain substantial knowledge gaps concerning zoochorous dispersal of freshwater IAS, and in order to comply with good preventative biosecurity practices, potential vectors will need to be examined in more detail. Here, we identify key areas for further study, realistic opportunities for data collection, and management protocols for mitigation of IAS spread.

The ability of freshwater fish to disperse invasive bivalves merits further investigation. In particular, knowledge of gut retention times for a catalogue of potential vector species is needed (Gatlin et al., 2013). Gut retention and survival of endozoochory can be analysed through ex situ feeding trials, focussing on the appearance of viable adult bivalves within gut or faecal samples. Such knowledge can be used to mitigate against further bivalve spread, by developing minimum quarantine times for fish caught and relocated for restocking purposes. Equally, other potential zoochorous vectors also need to be considered. For example, large semi-aquatic mammals have been shown to externally transport various aquatic invertebrates (Waterkeyn et al., 2010). Moreover, possible dispersal of bivalves by other freshwater inhabitants such as crayfish, freshwater turtles, and Odonatanymphs should be examined in greater detail. While management of natural dispersal by vector organisms is problematic in the extreme (Solarz et al., 2017), any animal which is deliberately taken from an invaded site, or equally, a site classified as being at risk of invasion, should be examined for the external adherence of 'hitch-hikers'. This is of particular importance if the animal is to be relocated and released into an uninvaded site.Awareness of zoochory and the importance of incidental in situ data collection needs to be promoted. A variety of nature enthusiasts, photographers, ecologists, conservationists, game hunters, wildlife and fisheries officers, bird ringers and field ornithologists come in contact with, deliberately observe, and often handle a variety of wildlife. It is not unlikely that instances of zoochory have been observed but remain undocumented. Notable examples include Green and Figuerola (2005) and Tøttrup et al. (2010), who documented the adherence of live cockle Cerastoderma edule to shorebirds $(n=4)$, and the attachment of non-native barnacles (up to $>30$ individual adult specimens) to migratory lesser black-backed gulls Larus fuscus $(n=7)$, respectively. Moreover, inseveral studies the combing of plumage has highlighted the adherence of invertebrates to waterbirds (e.g., Reynolds and Cumming, 2015). Therefore, in order to accurately determine the frequency of bird-mediated ectozoochory, bird ringers and game hunters should be incentivised to work with research groups to provide greater access to samples. Citizen science initiatives to increase the collection and cataloguing of such observations across all potential vector taxa should be encouraged by IAS managers and research groups. Equally, as part of citizen science initiatives, anglers or game hunters should be encouraged to examine gut contents of caught fish or birds and report any intact adult bivalves found.

While this review has focused on zoochorous dispersal of invasive freshwater bivalves, a growing body of research suggests zoochory may contribute to the spread of a wide variety of IAS, including gastropoda, amphipoda and freshwater arthropoda (e.g., juvenile crayfish) (Swanson, 1984; Reynolds et al., 2015; Green, 2016). Notably, New Zealand mud snails (Potamopyrgus antipodarum), an emerging freshwater invader in the USA, has been shown to survive gut passage through several fish species (see Bruce et al., 2009). Accordingly, the incorporation of zoochory biosecurity measures (e.g., quarantine times) is urgently required within IAS management strategies to mitigate against local invader spread.

Acknowledgments. N.E. Coughlan and J.T.A. Dick are supported by the Irish EPA Research grant 2015-NC-MS-4: Prevention, control and eradication of invasive alien species. We thank anonymous reviewers for helpful comments.

\section{Author contributions}

NEC conceived and designed the review; NEC and ALS conducted the review and analysis; all authors contributed to the writing of the manuscript, which was led by NEC.

\section{References}

Águas M, Banha F, Marques M, Anastácio PM. 2014. Can recentlyhatched crayfish cling to moving ducks and be transported during flight? Limnologica 48: 65-70.

Aguilar R, Ogburn MB, Driskell AC, Weigt LA, Mary C, Groves MC, Hines AH. 2016. Gutsy genetics: identification of digested piscine prey items in the stomach contents of sympatric native and introduced warmwater catfishes via DNA barcoding. Environ Biol Fishes 100: 325-336.

Aldridge DC, Ho S, Froufe E. 2014. The Ponto-Caspian quagga mussel, Dreissena rostriformis bugensis (Andrusov, 1897), invades Great Britain. Aquat Invas 9: 529-535.

Andraso G, Cowles J, Colt R, Patel J, Campbell M. 2011. Ontogenetic changes in pharyngeal morphology correlate with a diet shift from arthropods to dreissenid mussels in round gobies (Neogobius melanostomus). J Great Lakes Res 37: 738-743.

Anastácio PM, Ferreira MP, Banha F, Capinha C, Rabaça JE. 2014. Waterbird-mediated passive dispersal is a viable process for crayfish (Procambarus clarkii). Aquat Ecol 48: 1-10.

Banha F, Marques M, Anastácio PM. 2014. Dispersal of two freshwater invasive macroinvertebrates, Procambarus clarkii and Physella acuta, by off-road vehicles. Aquat Conserv Mar Freshw Ecosyst 24: 582-591.

Banha F, Gimeno I, Lanao M, Touya V, Durán C, Peribáñez M, Anastácio P. 2016. The role of waterfowl and fishing gear on zebra mussel larvae dispersal. Biol Invasions 18: 115-125.

Belz CE, Darrigran G, Mäder Netto OS, Boeger WA, Ribeiro Junior PJ. 2012. Analysis of four dispersion vectors in inland waters: the case of the invading bivalves in South America. J Shellfish Res 31: 777-784.

Benson AJ. 2014. Chronological history of zebra and quagga mussels (Dreissinidae) in North America, 1988-2010. In: Nalepa TF, Schloesser DW, eds. Quagga and Zebra mussels: Biology, Impacts and Control, 2nd edn. Florida: Taylor and Francis Group, pp. 9-31.

Beyer J, Moy P, De Stasio B. 2011. Acute upper thermal limits of three aquatic invasive invertebrates: hot water treatment to prevent upstream transport of invasive species. Environ Manag 47: 67-76.

Bilton DT, Freeland JR, Okamura B. 2001. Dispersal in freshwater invertebrates. Annu Rev Ecol Syst 32: 159-181.

Bouchard RW, Ferrington LC, Karius ML. 2004. Guide to aquatic invertebrates of the Upper Midwest. Identification manual for students, citizen monitors, and aquatic resource professionals. University of Minnesota. 
Brown RJ. 2007. Freshwater mollusks survive fish gut passage. Artic 60: 124-128.

Bruce RL, Moffitt CM, Dennis B. 2009. Survival and passage of ingested New Zealand mudsnails through the intestinal tract of rainbow trout. North Am J Aquac 71: 287-301.

Byrne RA, McMahon RF, Dietz TH. 1988. Temperature and relative humidity effects on aerial exposure tolerance in the freshwater bivalve Corbicula fluminea. Biol Bull 175: 253-260.

Caffrey J, Dick J, Lucy F, Davis E, Niven A, Coughlan N. 2016. First record of the Asian clam Corbicula fluminea (Müller, 1774) (Bivalvia, Cyrenidae) in Northern Ireland. BioInvasions Rec 5: 239-244.

Coughlan NE, Kelly TC, Davenport J, Jansen MAK. 2015a. Humid microclimates within the plumage of mallard ducks (Anas platyrhynchos) can potentially facilitate long distance dispersal of propagules. Acta Oecol 65-66: 17-23.

Coughlan NE, Kelly TC, Jansen MAK. 2015b. Mallard duck (Anas platyrhynchos)-mediated dispersal of Lemnaceae: a contributing factor in the spread of invasive Lemna minuta? Plant Biol 17 (Suppl. 1): 108-114.

Coughlan NE, Kelly TC, Davenport J, Jansen MAK. 2017a. Up, up and away: bird-mediated ectozoochorous dispersal between aquatic environments. Freshw Biol 62: 631-648.

Coughlan NE, Kelly TC, Jansen MAK. 2017b. "Step by step": high frequency short-distance epizoochorous dispersal of aquatic macrophytes. Biol Invasions 19: 625-634.

De M, Ghaffar MA, Bakar Y, Das SK. 2016. Effect of temperature and diet on growth and gastric emptying time of the hybrid, Epinephelus fuscoguttatus $\$ \times$ E. lanceolatus $\widehat{0}$. Aquac Reports 4: $118-124$

Douda K, Velíšek J, Kolářová J, Rylková K, Slavík O, Horký P, Langrová I. 2017. Direct impact of invasive bivalve (Sinanodonta woodiana) parasitism on freshwater fish physiology: evidence and implications. Biol Invasions 19: 989-999.

Duuriš Z, Horká I, Petrusek A. 2007. Invasive zebra mussel colonisation of invasive crayfish: a case study. Hydrobiologia 590: 43-46.

Essl F, Bacher S, Blackburn TM, Booy O, Brundu G, Brunel S, et al. 2015. Crossing frontiers in tackling pathways of biological invasions. BioScience 65: 769-782.

Fincke OM, Tylczak LA. 2011. Effects of zebra mussel attachment on the foraging behaviour of a larval dragonfly, Macromia illinoiensis. Ecol Entomol 36: 760-767.

Gatlin MR, Shoup DE, Long JM. 2013. Invasive zebra mussels (Driessena polymorpha) and Asian clams (Corbicula fluminea) survive gut passage of migratory fish species: implications for dispersal. Biol Invasions 15: 1195-1200.

Green AJ. 2016. The importance of waterbirds as an overlooked pathway of invasion for alien species. Divers Distrib 22: 239-247.

Green AJ, Figuerola J. 2005. Recent advances in the study of long distance dispersal of aquatic invertebrates via birds. Divers Distrib 11: $149-156$.

Gurney KEB, Clark RG, Slattery SM, Ross LCM. 2017. Connecting the trophic dots: responses of an aquatic bird species to variable abundance of macroinvertebrates in northern boreal wetlands. Hydrobiologia 785: 1-17.

Hamilton DJ, Davison Ankney C. 1994. Consumption of zebra mussels Dreissena polymorpha by diving ducks in Lakes Erie and St. Clair. Wildfowl 45: 159-166.

Higgins SN, Vander Zanden MJ. 2010. What a difference a species makes: a meta-analysis of dreissenid mussel impacts on freshwater ecosystems. Ecol Monogr 80: 179-196.

Hughes ME, Fincke OM. 2012. Reciprocal effects between burying behavior of a larval dragonfly (Odonata: Macromia illinoiensis) and zebra mussel colonization. $J$ Insect Behav 25: 554-568.
Hulme PE, Bacher S, Kenis M, Klotz S, Kühn I, Minchin D, et al. 2008. Grasping at the routes of biological invasions: a framework for integrating pathways into policy. J Appl Ecol 45: 403-414.

Hulme PE, Bacher S, Kenis M, Kühn I, Pergl J, Pyšek P, Roques A, Vilà M. 2016. Blurring alien introduction pathways risks losing the focus on invasive species policy. Conserv Lett, doi: 10.1111/ conl.12262.

Incagnone G, Marrone F, Barone R, Robba L, Nasselli-Flores L. 2015. How do freshwater organisms cross the "dry ocean"? A review on passive dispersal and colonization processes with a special focus on temporary ponds. Hydrobiologia 750: 103-123.

Johnson LE, Carlton JT. 1996. Post-establishment spread in largescale invasions: Dispersal mechanisms of the zebra mussel Dreissena polymorpha. Ecology 77: 1686-1690.

Karatayev AY, Burlakova LE, Padilla DK. 2015. Zebra versus quagga mussels: a review of their spread, population dynamics, and ecosystem impacts. Hydrobiologia 746: 97-112.

Kappes H, Haase P. 2012. Slow, but steady: dispersal of freshwater molluscs. Aquat Sci 74: 1-14.

Kohl KD, Ciminari ME, Chediack JG, Leafloor JO, Karasov WH, McWilliams SR, Caviedes-Vidal E. 2017. Modulation of digestive enzyme activities in the avian digestive tract in relation to diet composition and quality. J Com Physiol B 197: 339-351.

Lucy FE, Karatayev AY, Burlakova LE. 2012. Predictions for the spread, population density, and impacts of Corbicula flumineain Ireland. Aquat Invasions 7: 465-474.

MacAvoy SE, Macko SA, McIninch SP, Garman GC. 2000. Marine nutrient contributions to freshwater apex predators. Oecologia 122 : $568-573$.

Mack TN, Andraso G. 2015. Ostracods and other prey survive passage through the gut of round goby (Neogobius melanostomus). $J$ Great Lakes Res 41: 303-306.

Mackie GL. 1979. Dispersal mechanisms in Sphaeriidae (Mollusca: Bivalvia). Bull Am Malacol Union 45: 17-21.

Mackie GL. 1991. Biology of the exotic zebra mussel, Dreissena polymorpha, in relation to native bivalves and its potential impact in Lake St. Clair. Hydrobiologia 219: 251-268.

Marescaux J, Bij de Vaate A, Van Doninck K. 2012. First records of Dreissena rostriformis bugensis (Andrusov, 1897) in the Meuse River. BioInvasions Records 1: 109-114.

McMahon RF. 1979 Response to temperature and hypoxia in the oxygen consumption of the introduced asiatic freshwater clam Corbicula fluminea (Müller). Comp Biochem Physiol Part A: Physiol 63: 383-388.

McMahon R. 1982. The occurrence and spread of the introduced Asiatic freshwater clam Corbicula fluminea (Müller), in North America: 1924-1982. Nautilus 96: 134-141.

McMahon RF. 2002. Evolutionary and physiological adaptations of aquatic invasive animals: $r$ selection versus resistance. Can J Fish Aquatic Sci 59: 1235-1244.

McMahon RF, Ussery TA. 1995. Thermal tolerance of zebra mussels (Dreissena polymorpha) relative to rate of temperature increase and acclimation temperature. Technical Report EL-95-10. Vicksburg, MS: U.S. Army Engineer Waterways Experiment Station.

Mizanur RM, Yun H, Moniruzzaman M, Ferreira F, Kim KW, Bai SC. 2014. Effects of feeding rate and water temperature on growth and body composition of juvenile Korean Rockfish, Sebastes schlegeli (Hilgendorf 1880). Asian-Australas J Anim Sci 27: 690-699.

Perello MM, Simon TP, Thompson HA, Kane DD. 2015. Feeding ecology of the invasive round goby, Neogobius melanostomus (Pallas, 1814), based on laboratory size preference and field diet in different habitats in the western basin of Lake Erie. Aquat Invasions 10: $463-474$ 
Piersma T, Koolhaas A, Dekinga A. 1993. Interactions between stomach structure and diet choice in shorebirds. Auk 110: $552-564$

Pimentel D, Zuniga R, Morrison D. 2005. Update on the environmental and economic costs associated with alien-invasive species in the United States. Ecol Econ 52: 273-288.

Rees WJ. 1965. The aerial dispersal of mollusca. Proc Malacol Soc Lond 36: 269.

Reynolds C, Cumming GS. 2015. The role of waterbirds in the dispersal of freshwater cladocera and bryozoa in southern Africa. Afr Zool 50: 307-311.

Reynolds C, Miranda NAF, Cumming GS. 2015. The role of waterbirds in the dispersal of aquatic alien and invasive species. Divers Distrib 21: 744-754.

Ricciardi A, Serrouya R, Whoriskey FG. 1995. Aerial exposure tolerance of zebra and quagga mussels (Bivalvia: Dreissenidae): implications for overland dispersal. Can J Fish Aquat Sci 52: 470-477.

Robinson JV, Wellborn GA. 1988. Ecological resistance to the invasion of a freshwater clam, Corbicula fluminea: fish predation effects. Oecologia 77: 445-452.

Soomers H, Karssenberg D, Soons MB, Verweij PA, Verhoeven JTA, Wassen MJ. 2013. Wind and water dispersal of wetland plants across fragmented landscapes. Ecosystems 16: 434-451.

Solarz W, Najberek K, Pociecha A, Wilk-Woźniak E. 2017. Birds and alien species dispersal: on the need to focus management efforts on primary introduction pathways - comment on Reynolds et al. and Green. Divers Distrib 23: 113-117.

Sousa R, Gutierrez JL, Aldridge DC. 2009. Non-indigenous invasive bivalves as ecosystem engineers. Biol Invasions 11: 2367-2385.

Sousa R, Novais A, Costa R, Strayer DL. 2014. Invasive bivalves in fresh waters: impacts from individuals to ecosystems and possible control strategies. Hydrobiologia 735: 233-251.

Spidle AP, Mills EL, May B. 1995. Limits to tolerance of temperature and salinity in the quagga mussel (Dreissena bugensis) and the zebra mussel (Dreissena polymorpha). Can J Fish Aquat Sci 52: 2108-2119.
Strayer DL, Caraco NF, Cole JJ, Findlay S, Pace ML. 1999. Transformation of freshwater ecosystems by bivalves: a case study of zebra mussels in the Hudson River. Bioscience 49: 19-27.

Swanson GA. 1984. Dissemination of amphipods by waterfowl. $J$ Wildlife Manag 48: 988-991.

Thompson HA, Simon TP. 2014. Diet shift response in round goby, Neogobius melanostomus, based on size, sex, depth, and habitat in the western basin of Lake Erie. J Appl Ichthyol 30: 955-961.

Thompson CM, Sparks RE. 1977. Improbability of dispersal of adult Asiatic clams, Corbiulca manilensis, via the intestinal tract of migratory waterfowl. Am Midl Nat 98: 219-223.

Tøttrup AP, Chan BKK, Koskinen H, Høeg JH. 2010. 'Flying barnacles': implications for the spread of non-indigenous species. Biofouling 26: 577-582.

Tripp SJ, Hill MJ, Calkins HA, Brooks RC, Herzog DP, Ostendorf DE, Hrabik RA, Garvey JE. 2011. Blue catfish movement in the upper Mississippi River. In: Michaletz PH, Travnichek VH, eds. Conservation, ecology, and management of catfish: the second international symposium. American Fisheries Society, Symposium 77, Bethesda, Maryland, pp. 511-519.

Tucker JK, Cronin FA, Soergel DW, Theiling CH. 1996. Predation on Zebra Mussels (Dreissena polymorpha) by Common Carp (Cyprinus carpio). J Freshw Ecol 11: 363-372.

van Gils JA, Piersma T, Anne Dekinga A, Dietz MW. 2003. Costbenefit analysis of mollusc-eating in a shorebird II. Optimizing gizzard size in the face of seasonal demands. J Exp Biol 206: 3369-3380.

van Leeuwen CHA, van der Velde G, van Lith B, Klaassen M. 2012. Experimental quantification of long distance dispersal potential of aquatic snails in the gut of migratory birds. PLoS ONE 7: e32292.

Voelz NJ, McArthur JV, Rader RB. 1998. Upstream mobility of the Asiatic clam Corbicula fluminea: identifying potential dispersal agents. J Freshw Ecol 13: 39-45.

Waterkeyn A, Pineau O, Grillas P, Brendonck L. 2010. Invertebrate dispersal by aquatic mammals: a case study with nutria Myocastor coypus (Rodentia, Mammalia) in Southern France. Hydrobiologia 654: 267-271.

Cite this article as: Coughlan NE, Stevens AL, Kelly TC, Dick JTA, Jansen MAK. 2017. Zoochorous dispersal of freshwater bivalves: an overlooked vector in biological invasions? Knowl. Manag. Aquat. Ecosyst., 418, 42. 